\title{
Ongoing CMV Infection (qPCR+), Nodular Thyroiditis and Periodontitis are Associated with Ileal Distension (Ileal Brake), Cancer and Increased Plasmatic Hyaluronic Acid Levels
}

\author{
Donatini Bruno* and Le Blaye Isabelle \\ Medicine Information Formation SA (Research), Cormontreuil, France
}

*Corresponding author: Donatini Bruno, Medicine Information Formation SA (Research), Cormontreuil, France, Tel: 06-08-58-46-29; E-mail: donatini@orange.fr

Received: 25 Sep, 2019 | Accepted: 09 Oct, 2019 | Published: 21 Oct, 2019

Citation: Donatini B, Le Blaye I (2019) Ongoing CMV Infection (qPCR+), Nodular Thyroiditis and Periodontitis are Associated with lleal Distension (lleal Brake), Cancer and Increased Plasmatic Hyaluronic Acid Levels. J Clin Case Stu 5(1): dx.doi.org/10.16966/2471-4925.195

Copyright: (C) 2019 Donatini B, et al. This is an open-access article distributed under the terms of the Creative Commons Attribution License, which permits unrestricted use, distribution, and reproduction in any medium, provided the original author and source are credited.

Abstract

Background: Periodontitis (PO) and Nodular Thyroiditis (NT) are associated with CMV infection and metabolic syndrome, and an increased risk of polyps or colorectal cancer.

Objective: We investigated whether oral CMV replication is more frequent in patients with PO+NT and with a medical history of cancer or overweight.

Methods: All data were collected during routine consultations for Small Intestinal Bowel Overgrowth (SIBO).CMV IgG serology, CMV DNA (qPCR) in saliva, plasmatic Hyaluronic Acid (HA) dosage, transabdominal and thyroid ultrasound examinations were routinely performed in SIBO.

Results: 196 patients were included. 70 patients presented with NT, 59 with PO, 32 patients with NT+PO. 26 patients have CMV DNA in their saliva (13.3\%). 12 patients had a medical history of cancer.

Patients without NT (116 patients) and without ongoing CMV replication (110) presented with low percentages of cancer, ileal brake or low plasmatic HA levels i.e., $3 \%, 22 \%$ and $43 \pm 42 \mu \mathrm{g} / \mathrm{l}$ respectively. Patients (16) with ongoing CMV replication have increased rates of cancer $(6 \% ; p<0.01)$ and of ileal brake $(50 \% ; p<0.001)$.

Patients without $\mathrm{PO}$ and without ongoing CMV replication (119 patients) presented with low percentage of cancer, ileal brake or low plasmatic HA levels: respectively $3 \%, 19 \%, 41.5 \pm 40 \mu \mathrm{g} / \mathrm{l}$. Patients (18) with ongoing CMV replication have increased rates of cancer $(11 \% ; p<0.001)$ and of ileal brake (39\%; $p<0.001)$.

Patients (6) with NT+periodontitis and with ongoing CMV infection experienced more frequently cancer (50\%) or ileal brake (80\%) than those (27) without ongoing CMV infection: respectively $11 \%(p<0.001)$ and $37 \%(p<0.05)$. The level of HA was also higher in patients with $q P C R+(98 \pm 50$ versus $56 \pm 40 ; p<0.05$ ).

Conclusion: Oral active CMV infection appears to be associated with severe tissue destruction, ileal brake/overweight and medical history of cancer.

Keywords: Nodular Thyroiditis; Periodontitis; CMV; Ileal brake; Hyaluronic acid

\section{Introduction}

Periodontitis (PO) concerns more than $10 \%$ of the population [1] and is associated with Metabolic Syndrome (MS) [2-5] or cancers of mucosa in contact with the digestive microbiota [6-10].

Chronic mucosal inflammation induced by an oral or a small gut dysbiosis may lead to deleterious interactome [11].

PO has been attributed to specific types of bacteria such as Fusobacterium nucleatum, Aggregatibacter actinomycetemcomitans, Porphyromonas gingivalis, Prevotella intermedia, Tannarella forsythia, Campylobacter rectus, Eubacterium nodatum, Peptostreptococcus micros or Treponema species [12,13].
Some cancers have been attributed to Fusobacterium nucleatum (which belongs to $\mathrm{PO}$-associated pathogens), especially colonic cancer [14].

The severity of PO is also associated (even attributed by some authors) to the expression of herpes viruses, including cytomegalovirus [15-18]. The association of cytomegalovirus and Aggregatibacter actinomycetemcomitans could explain severe progression of PO [19].

Multiple herpesvirus infection is detected in patients with severe chronic PO. Herpes Simplex Virus (HSV)-1 (46.6\%) are the most common herpesvirus followed by HSV-2 (34.6\%), Epstein-Barr Viruses (EBV) (30.6\%), and Cytomegalovirus (CMV) (19.3\%) [20]. Cytomegalovirus has also been implicated in the occurrence of central 
obesity [21,22], immunosenescence [23,24], gastric cancer [25,26] and early diverticulitis $[27,28]$. The prevalence of oral cytomegalovirus in gingival crevicular fluid varies according to the severity of the disease and ranges between 12 and 20\% [29]. The prevalence of CMV in subgingival plaques reaches $54.5 \%$ in patients with chronic $\mathrm{PO}$ versus $27.5 \%$ in healthy patients [30]. The prevalence of thyroid nodules in subjects with colorectal polyps is significantly higher than in healthy controls $[31,32]$.

In preliminary studies, we reported that severe PO is associated with an increased level of Low Molecular Weight-Hyaluronic Acid (LMW-HA), and with an increased risk of adenocarcinoma [33-35] or of thyroiditis [36].

LMW-HA is known to increase endothelial permeability, to stimulate receptors of cancer stem cells and to favour cancer cells metastasis [37-40].

We investigated whether oral replication of CMV is associated with a medical history of cancer, overweight, thyroid nodules, and an increased plasmatic level of LMW-HA.

\section{Material and Methods}

All data were collected during the normal course of routine gastroenterological consultations for Small Intestinal Bowel Overgrowth, from April 16, 2018 until April 15, 2019. There was no hypothesis testing before data collection, no data collection beyond that which is part of routine clinical practice, no scheduled data analysis before the work has already been done. This retrospective analysis of case series cannot therefore be qualify as "research" and does not requires approval from ethics boards designed to protect humans involved in clinical research.

\section{Inclusion criteria}

Patients consulting for SIBO. Patients should provide with a full medical history, especially regarding $\mathrm{PO}$, thyroid pathologies, body weight and height, diabetes mellitus. Diabetes mellitus, when present, should be stabilized. CMV IgG serology, CMV DNA (qPCR) in saliva and plasmatic Hyaluronic Acid (HA) dosage are routinely performed in patients consulting for SIBO. All patients coming for SIBO underwent a breath test, a transabdominal ultrasound and a thyroid ultrasound (also routinely performed in SIBO).

Patients signed a written consent for the epidemiological use of collected data; as all other patients consulting in the gastroenterological clinic.

\section{Exclusion criteria}

Ongoing tobacco abuse; lack of CMV DNA analysis; lack of by breath test or transabdominal ultrasound; lack of signed consent for epidemiological use of data; uncontrolled diabetes mellitus.

\section{DNA viral or bacterial analysis}

CMV DNA was detected by qPCR (Amplix ${ }^{\oplus}$ from Alldiag; reagents: Bioneer ${ }^{\circ}$ ) in oral swabs. Samples were collected at $-18^{\circ} \mathrm{C}$ and all analysed the same day in a centralized lab.

\section{Ultrasound}

Ileal brake was diagnosed as soon as ileal diameter reached $2.2 \mathrm{~cm}$ at the ileo-coecal junction [41]. Nodular thyroiditis was diagnosed as soon as nodules above $3 \mathrm{~mm}$ were measured.

\section{Statistics}

Comparisons of means were performed using independent
Student's t-test. Comparisons of percentage used two-sample t-tests. Yates correction was used for small samples.

\section{Results}

This descriptive research study included 196 patients.70 patients presented with nodular thyroiditis, 59 with $\mathrm{PO}, 32$ patients with NT associated with PO. 26 patients have CMV DNA in their saliva (13.3\%). 12 patients had a medical history of cancer. The descriptive demographic data according to NT and PO status is summarized in table 1 .

The mean body weight of patients with an ileal brake was higher than those without an ileal brake $(80.3 \mathrm{~kg} \pm 19.3$ versus $62.6 \mathrm{~kg} \pm 14.2$; $\mathrm{p}<0.001)$ although their height was similar $(167 \mathrm{~cm} \pm 22$ versus 167 $\mathrm{cm} \pm 13)$.

Patients without NT and without ongoing CMV infection presented with low percentage of cancer or of ileal brake i.e., $3 \%$ and $22 \%$ respectively. Patients with ongoing CMV replication have increased rates of cancer $(6 \% ; \mathrm{p}<0.01)$ and of ileal brake $(50 \%$; $\mathrm{p}<0.001$ ) (Table 2).

Patients without PO and without ongoing CMV infection presented with low percentage of cancer or of ileal brake i.e., 3\% and $19 \%$ respectively. Patients with ongoing CMV replication have increased rates of cancer $(11 \%$; $<<0.001)$ and of ileal brake $(39 \%$; $\mathrm{p}<0.001$ ) (Table 2).

Patients with NT+PO have higher percentage of cancer (19\%) or ileal brake (50\%) and higher level of HA $(69 \pm 42)$ than those with NT only or PO only $(\mathrm{p}<0.001$ in all instances) (Table 3$)$.

Patients with $\mathrm{NT}+\mathrm{PO}$ and with ongoing $\mathrm{CMV}$ infection experienced more frequently cancer $(50 \%)$ or ileal brake $(80 \%)$ than those without ongoing CMV infection: respectively $11 \%(\mathrm{p}<0.001)$ and $37 \%(\mathrm{p}<0.05)$. The level of LMW-HA was also higher in patients with qPCR+ $(98 \pm 50$ versus $56 \pm 40 ; \mathrm{p}<0.05$ ) (Table 4 ).

\section{Discussion}

Oral active CMV infection can be detected by qPCR. The prevalence of oral cytomegalovirus in gingival crevicular fluid varies according to the severity of the disease and ranges between 12 to $20 \%$ [29]. In this work we found CMV-DNA in $13.6 \%$ of patients with PO. This figure is much lower than the prevalence mentioned in studies focussed on subgingival plaques. In this latter instance the expected percentage would be close to $27.5 \%$ in healthy patients and $54.5 \%$ of patients with PO [30]. Saliva or gingival crevicular fluid appears therefore less contaminated than subgingival plaques.

Table 1: Descriptive demographic data according to PO and NT status.

\begin{tabular}{|l|l|c|c|c|}
\hline & \multicolumn{1}{|c|}{ Gender } & Age & Body weight (kg) & Height (cm) \\
\hline $\begin{array}{l}\text { NT without PO } \\
\text { (38 patients) }\end{array}$ & $\begin{array}{l}\text { Male: 29\% } \\
\text { Female: } 71 \%\end{array}$ & $49 \pm 14$ & $69.0 \pm 21.4$ & $168.2 \pm 8.0$ \\
\hline $\begin{array}{l}\text { PO without NT } \\
\text { (27 patients) }\end{array}$ & $\begin{array}{l}\text { Male: } 45 \% \\
\text { Female: } 55 \%\end{array}$ & $48 \pm 15$ & $67.9 \pm 14.1$ & $169.6 \pm 13.4$ \\
\hline $\begin{array}{l}\text { NT and PO } \\
\text { (32 patients) }\end{array}$ & $\begin{array}{l}\text { Male: } 38 \% \\
\text { Female: 62\% }\end{array}$ & $56 \pm 12$ & $68.0 \pm 19.6$ & $169.8 \pm 8.7$ \\
\hline $\begin{array}{l}\text { Neither NT } \\
\text { nor PO (99 } \\
\text { patients) }\end{array}$ & $\begin{array}{l}\text { Male: } 41 \% \\
\text { Female: } 59 \%\end{array}$ & $46 \pm 12$ & $64.8 \pm 16.4$ & $169.4 \pm 8.8$ \\
\hline $\begin{array}{l}\text { Total } \\
\text { (196 patients) }\end{array}$ & $\begin{array}{l}\text { Male: } 39 \% \\
\text { Female: } 61 \%\end{array}$ & $49 \pm 13$ & $68.5 \pm 18.1$ & $169.3 \pm 9.6$ \\
\hline
\end{tabular}


Table 2: Percentages of patients with cancer, ileal brake and plasmatic HA concentrations according to NT, PO and/or CMV status.

\begin{tabular}{|c|c|c|c|c|}
\hline & NT (70 patients) & No NT (126 patients) & PO (59 patients) & No PO (137 patients) \\
\hline $\begin{array}{l}\text { qPCR CMV + } \\
\text { CMV IgG + }\end{array}$ & $\begin{array}{l}6 \text { patients } \\
2 \text { cancers }(33 \%)^{*} \\
4 \text { ileal brakes }(67 \%) \\
\text { Plasmatic HA: } 51 \pm 22 \mu \mathrm{g} / \mathrm{l}\end{array}$ & $\begin{array}{l}16 \text { patients } \\
1 \text { cancer }(6 \%)^{*} \\
8 \text { ileal brake }(50 \%) \\
\text { Plasmatic HA: } 52 \pm 41 \mu \mathrm{g} / \mathrm{l}\end{array}$ & $\begin{array}{l}8 \text { patients } \\
2 \text { cancers }(25 \%)^{* *} \\
5 \text { ileal brakes }(62.5 \%) \text { ! } \\
\text { Plasmatic HA: } 56 \pm 42 \mu \mathrm{g} / \mathrm{l}\end{array}$ & $\begin{array}{l}18 \text { patients } \\
2 \text { cancers }(11 \%)^{* *} \\
7 \text { ileal brakes }(39 \%) \text { ! } \\
\text { Plasmatic HA: } 49 \pm 31 \mu \mathrm{g} / \mathrm{l}\end{array}$ \\
\hline $\begin{array}{l}\text { qPCR CMV + } \\
\text { CMV IgG - }\end{array}$ & $\begin{array}{l}4 \text { patients } \\
\text { (all with lymphopenia and } \\
\text { hypogammaglobulinemia) } \\
1 \text { cancer }(25 \%) \\
\text { No ileal brake }(0 \%) \\
\text { Plasmatic HA: } 8.5 \pm 2.1\end{array}$ & None & None & None \\
\hline $\begin{array}{l}\text { qPCR CMV - } \\
\text { CMV IgG + }\end{array}$ & $\begin{array}{l}36 \text { patients } \\
3 \text { cancers }(8 \%) \\
10 \text { ileal brakes }(27 \%) \\
\text { Plasmatic HA: } 53 \pm 50 \mu \mathrm{g} / \mathrm{l}\end{array}$ & $\begin{array}{l}40 \text { patients } \\
2 \text { cancers }(5 \%) \\
10 \text { ileal brakes }(25 \%) \\
\text { Plasmatic HA: } 43 \pm 40 \mu \mathrm{g} / \mathrm{l}\end{array}$ & $\begin{array}{l}36 \text { patients } \\
3 \text { cancers ( } 8 \%) \\
13 \text { ileal brakes ( } 36 \%) \\
\text { Plasmatic HA: } 55 \pm 56 \mu \mathrm{g} / \mathrm{l}\end{array}$ & $\begin{array}{l}45 \text { patients } \\
\text { Two cancers (4\%) } \\
11 \text { ileal brakes }(24 \%) \\
\text { Plasmatic HA: } 44 \pm 40 \mu \mathrm{g} / \mathrm{l}\end{array}$ \\
\hline $\begin{array}{l}\text { qPCR CMV - } \\
\text { CMV IgG - }\end{array}$ & $\begin{array}{l}24 \text { patients } \\
2 \text { cancers }(8 \%) \\
6 \text { ileal brake }(25 \%) \\
\text { Plasmatic HA: } 49 \pm 47 \mu \mathrm{g} / \mathrm{l}\end{array}$ & $\begin{array}{l}70 \text { patients } \\
\text { One cancer ( } 2 \%) \\
14 \text { ileal brakes }(20 \%) \\
\text { Plasmatic HA: } 43 \pm 42 \mu \mathrm{g} / \mathrm{l}\end{array}$ & $\begin{array}{l}15 \text { patients } \\
\text { One cancer }(7 \%) \\
4 \text { ileal brakes }(27 \%) \\
\text { Plasmatic HA: } 50 \pm 46 \mu \mathrm{g} / \mathrm{l}\end{array}$ & $\begin{array}{l}74 \text { patients } \\
\text { Two cancers (3\%) } \\
12 \text { ileal brakes }(16 \%) \\
\text { Plasmatic HA: } 40 \pm 38 \mu \mathrm{g} / \mathrm{l}\end{array}$ \\
\hline
\end{tabular}

$* p<0.01$

$* * p<0.001$

$! p<0.001$

Table 3: Percentages of patients with cancer, ileal brake and plasmatic HA concentrations according to NT and/or PO status.

\begin{tabular}{|c|c|c|}
\hline & NT (70 patients) & No NT (126 patients) \\
\hline PO & $\begin{array}{l}32 \text { patients } \\
6 \text { cancers }(19 \%)^{*} \\
16 \text { ileal brakes }(50 \%) ! \\
\text { Plasmatic HA: } 69 \pm 42 \mu \mathrm{g} / \mathrm{l} \S\end{array}$ & $\begin{array}{l}27 \text { patients } \\
2 \text { cancers }(7 \%)^{*} \\
6 \text { ileal brakes }(22 \%) \text { ! } \\
\text { Plasmatic HA: } 42 \pm 23 \mu \mathrm{g} / \mathrm{I} \S\end{array}$ \\
\hline No PO & $\begin{array}{l}38 \text { patients } \\
2 \text { cancers }(5 \%) \\
13 \text { ileal brakes ( } 34 \%) \\
\text { Plasmatic HA: } 43 \pm 23\end{array}$ & $\begin{array}{l}99 \text { patients } \\
2 \text { cancers }(2 \%) \\
17 \text { ileal brakes }(17 \%) \\
\text { Plasmatic HA: } 45 \pm 25\end{array}$ \\
\hline
\end{tabular}

$* p<0.001$

! $p<0.001$

$\S p<0.001$

The overall seroprevalence of CMV in the adult population in Europe can be estimated to be approximately 57\% [42], which is close to our findings (50\%).

Cytomegalovirus and periodontal bacteria could interact and favour severe PO [19]. Replication of viruses could be required for tissue damages.

In this descriptive research study, IgG seroprevalence without $\mathrm{CMV}$ replication is not associated with tissue inflammation or tissue destruction. However, active CMV replication is more frequent in patients with $\mathrm{PO}+\mathrm{NT}$. In this instance, high plasmatic LMW-HA levels, ileal break/overweight and a medical history of cancer (respectively $\mathrm{p}<0.001, \mathrm{p}<0.05$ and $\mathrm{p}<0.001)$ confirm global inflammation and tissue destruction.

Periodontal-concomitant local dysbiosis, which includes EBV, Helicobacter pylori or Porphyromonas gingivalis, may trigger
Table 4: Percentages of patients with cancer, ileal brake and plasmatic $\mathrm{HA}$ concentrations according to NT+PO and/or CMV status (results from patients with NT only or with PO only (68 patients) are not included).

\begin{tabular}{|c|c|c|}
\hline & $\begin{array}{c}\text { NT+PO } \\
\text { (33 patients) }\end{array}$ & $\begin{array}{c}\text { Neither NT nor PO } \\
\text { (95 patients) }\end{array}$ \\
\hline $\begin{array}{l}\text { qPCR CMV + } \\
\text { CMV IgG + }\end{array}$ & $\begin{array}{l}6 \text { patients } \\
3 \text { cancers }(50 \%)^{*} \\
5 \text { ileal brakes }(80 \%) ! \\
\text { Plasmatic HA: } 98 \pm 50 \mu \mathrm{g} / \mathrm{l} \S\end{array}$ & $\begin{array}{l}11 \text { patients } \\
\text { One cancer }(9 \%)^{*} \\
4 \text { ileal brakes }(36 \%) \\
\text { Plasmatic HA: } 48 \pm 38 \mu \mathrm{g} / \mathrm{l} \S\end{array}$ \\
\hline $\begin{array}{l}\text { qPCR CMV + } \\
\text { CMV IgG - }\end{array}$ & None & None \\
\hline $\begin{array}{l}\text { qPCR CMV - } \\
\text { CMV IgG + }\end{array}$ & $\begin{array}{l}23 \text { patients }=19 \\
3 \text { cancers }(13 \%) \\
9 \text { ileal brakes }(39 \%) \\
\text { Plasmatic HA: } 57 \pm 34\end{array}$ & $\begin{array}{l}34 \text { patients } \\
2 \text { cancers }(6 \%) \\
8 \text { ileal brakes }(24 \%) \\
\text { Plasmatic HA: } 47 \pm 45\end{array}$ \\
\hline $\begin{array}{l}\text { qPCR CMV - } \\
\text { CMV IgG - }\end{array}$ & $\begin{array}{l}4 \text { patients } \\
\text { No cancer } \\
\text { One ileal brake }(25 \%) \\
\text { Plasmatic HA: } 52 \pm 41\end{array}$ & $\begin{array}{l}50 \text { patients } \\
1 \text { cancer }(2 \%) \\
6 \text { ileal brakes }(12 \%) \\
\text { Plasmatic HA: } 42 \pm 35\end{array}$ \\
\hline
\end{tabular}

$*_{p}<0.001$

! $<<0.05$

$\S p<0.05$

inflammation and induce immunosuppression [43-45]. Consequently, oral CMV replication may be explained by immunosuppression caused by oral agents. However, CMV itself is an established cause of immunosenescence and premature global aging, in particular through accelerated methylation [46-47]. Obesity is also considered as a factor of premature aging due to dysmethylation [48].

Since the detection of DNA methylation signatures of thyroid nodules is considered to be a reliable method to differentiate malignant and benign thyroid lesions [49-53], methylation can explain a synergic detrimental effect of obesity and CMV replication on the thyroid. 
Metabolic, endocrine or cytokine secretions may also be involved in the inflammatory process. Ileal brake is a physiological reflex implicated in satiety [54-56]. Ileal inflation induces GLP-1 synthesis which blocks gastroduodenal voiding. A diameter of the ileocecal junction higher than $2.2 \mathrm{~cm}$ after 10 hours fasting (measured with a transabdominal ultrasound examination) highly suggests chronic ileal distension associated with an altered GLP-1 synthesis and a metabolic syndrome [41].

Altered GLP-1 synthesis may explain the association between PO and cardio-metabolic risk increase [57,58]. It also triggers CMV-induced inflammation of adipocytes with chronic low-grade inflammation due to an increased production of IL-6 leading to osteopenia, cardiovascular diseases and type 2 diabetes $[59,60]$.

$\mathrm{NT}$ is related to metabolic syndrome and metabolic disturbances [61-65]. However, this descriptive research study does not confirm NT or PO alone as risk factors of ileal brake, cancer or tissues destruction.

In addition, although early CMV infection may increase the risk of obesity and metabolic trait [66-68], previous CMV infection (CMV positive serology) without detectable oral CMV replication was not associated in this study with severe diseases in adults older than 50 years of age. To our knowledge, not previous study investigated the link between CMV oral active replication and obesity.

\section{Conclusion}

Oral active CMV replication appears to be associated with severe tissue destruction, ileal brake/overweight and a medical history of cancer. Clinician should check for NT and PO in their patients, especially when overweight is present. Ileal brake is an interesting parameter, easy and inexpensive to detect with transabdominal ultrasound examination. Plasmatic LMW-HA levels and qPCR for detection of CMV-DNA in saliva could be of interest in patients with $\mathrm{PO}+\mathrm{NT}$ in order to screen those with an increased risk of severe tissue destruction.

\section{Acknowledgment(s) and Conflicts of Interest}

No conflict of interest to disclose.

\section{References}

1. Frencken JE, Sharma P, Stenhouse L, Green D, Laverty D, et al. (2017) Global Epidemiology of Dental Caries and Severe Periodontitis-A Comprehensive Review. J Clin Periodontol 44: S94-S105.

2. Kaye EK, Chen N, Cabral HJ, Vokonas P, Garcia RI (2016) Metabolic Syndrome and Periodontal Disease Progression in Men. J Dent Res 95: 822-828.

3. Gaio EJ, Haas AN, Rosing CK, Oppermann RV, Albandar JM, et al. (2016) Effect of Obesity on Periodontal Attachment Loss Progression: A 5-Year Population-Based Prospective Study. J Clin Periodontol 43: 557-565.

4. Daudt LD, Musskopf ML, Mendez M, Remonti LLR, Leitao CB, et al. (2018) Association between Metabolic Syndrome and Periodontitis: A Systematic Review and Meta-Analysis. Braz Oral Res 32: e35.

5. Kim OS, Shin MH, Kweon SS, Lee YH, Kim OJ, et al. (2018) The Severity of Periodontitis and Metabolic Syndrome in Korean Population: The Dong-Gu Study. J Periodontal Res 53: 362-368.

6. Michaud DS, Kelsey KT, Papathanasiou E, Genco CA, Giovannucci E (2016) Periodontal Disease and Risk of All Cancers Among Male Never Smokers: An Updated Analysis of the Health Professionals Follow-up Study. Ann Oncol 27: 941-947.
7. Momen-Heravi F, Babic A, Tworoger SS, Zhang L, Wu K, et al. (2016) Periodontal Disease, Tooth Loss and Colorectal Cancer Risk: Results from the Nurses' Health Study. Int J Cancer 140: 646-652.

8. Maisonneuve P, Amar S, Lowenfels AB (2017) Periodontal Disease, Edentulism, and Pancreatic Cancer: A Meta-Analysis. Ann Oncol 28: 985-995.

9. Yang B, Petrick JL, Abnet CC, Graubard BI, Murphy G, et al. (2017) Tooth Loss and Liver Cancer Incidence in a Finnish Cohort. Cancer Causes Control 28: 899-904.

10. Ye L, Jiang Y, Liu W, Tao H (2016) Correlation between Periodontal Disease and Oral Cancer Risk: A Meta-Analysis. J Cancer Res Ther 12: C237-C240.

11. Carter CJ, France J, Crean S, Singhrao SK (2017) The Porphyromonas gingivalis/Host Interactome Shows Enrichment in GWASdb Genes Related to Alzheimer's Disease, Diabetes and Cardiovascular Diseases. Front Aging Neurosci 9: 408.

12. Meuric V, Le Gall-David S, Boyer E, Acuna-Amador L, Martin B, et al. (2017) Signature of Microbial Dysbiosis in Periodontitis. Appl Environ Microbiol 83: e00462-17.

13. Suda R, Kurihara C, Kurihara M, Sato T, Lai CH, et al. (2003) Determination of Eight Selected Periodontal Pathogens in the Subgingival Plaque of Maxillary First Molars in Japanese School Children Aged 8-11 Years. J Periodontal Res 38: 28-35.

14. Shang FM, Liu HL (2018) Fusobacterium nucleatum and Colorectal Cancer: A Review. World J Gastrointest Oncol 10: 71-81.

15. Vincent-Bugnas $S$, Vitale $S$, Mouline CC, Khaali W, Charbit $Y$, et al. (2013) EBV Infection is Common in Gingival Epithelial Cells of the Periodontium and Worsens during Chronic Periodontitis. PLoS One 8: e80336.

16. Aggarwal T, Lamba AK, Faraz F, Tandon S (2017) Viruses: Bystanders of Periodontal Disease. Microb Pathog 102: 54-58.

17. Shah R, Mehta DS (2016) Prevalence of Herpesviruses in Gingivitis and Chronic Periodontitis: Relationship to Clinical Parameters and Effect of Treatment. J Indian Soc Periodontol 20: 279-285.

18. Slots J, Saygun I, Sabeti M, Kubar A (2006) Epstein-Barr Virus in Oral Diseases. J Periodontal Res 41: 235-244.

19. Elamin A, Ali RW, Bakken V (2017) Putative Periodontopathic Bacteria and Herpes Viruses Interactions in the Subgingival Plaque of Patients with Aggressive Periodontitis and Healthy Controls. Clin Exp Dent Res 3: 183-190

20. Kazi MMAG, Bharadwaj R (2017) Role of Herpesviruses in Chronic Periodontitis and their Association with Clinical Parameters and in Increasing Severity of the Disease. Eur J Dent 11: 299-304.

21. Schooling CM, Jones HE, Leung GM (2011) Lifecourse Infectious Origins of Sexual Inequalities in Central Adiposity. Int J Epidemiol 40: 1556-1564.

22. Nabipour I, Vahdat K, Jafari SM, Pazoki R, Sanjdideh Z (2006) The Association of Metabolic Syndrome and Chlamydia pneumoniae, Helicobacter pylori, Cytomegalovirus, and Herpes Simplex Virus Type 1: The Persian Gulf Healthy Heart Study. Cardiovasc diabetol 5: 25.

23. Kananen L, Nevalainen T, Jylhava J, Marttila S, Hervonen A, et al. (2015) Cytomegalovirus Infection Accelerates Epigenetic Aging. Exp Gerontol 72: 227-229. 
24. Luetke-Eversloh M, Hammer Q, Durek P, Nordstrom K, Gasparoni G, et al. (2014) Human Cytomegalovirus Drives Epigenetic Imprinting of the IFNG Locus in NKG2C hi Natural Killer Cells. PLoS Pathogens 10: e1004441.

25. Fattahi S, Nikbakhsh N, Taheri H, Ghadami E, Kosari-Monfared M, et al. (2018) Prevalence of Multiple Infections and the Risk of Gastric Adenocarcinoma Development at Earlier Age. Diagn Microbiol Infect Dis 92: 62-68.

26. Del Moral-Hernandez O, Castanon-Sanchez CA, Reyes-Navarrete S, Martinez-Carrillo DN, Betancourt-Linares R, et al. (2019) Multiple Infections by EBV, HCMV and Helicobacter pylori are Highly Frequent in Patients with Chronic Gastritis and Gastric Cancer from Southwest Mexico: An Observational Study. Medicine (Baltimore) 98: e14124.

27. Schieffer KM, Kline BP, Harris LR, Deiling S, Koltun WA, et al. (2018) A Differential Host Response to Viral Infection Defines a Subset of Earlier-Onset Diverticulitis Patients. J Gastrointestin Liver Dis 27 : 249-255.

28. Hollink N, Dzabic M, Wolmer N, Bostrom L, Rahbar A (2007) High Prevalence of an Active Human Cytomegalovirus Infection in Patients with Colonic Diverticulitis. J Clin Virol 40: 116-119.

29. Shah R, Mehta DS (2016) Prevalence of Herpesviruses in Gingivitis and Chronic Periodontitis: Relationship to Clinical Parameters and Effect of Treatment. J Indian Soc Periodontol 20: 279-285.

30. Zhu C, Li F, Wong MC, Feng XP, Lu HX, et al. (2015) Association between Herpesviruses and Chronic Periodontitis: A Meta-Analysis Based on Case-Control Studies. PLoS One 10: e0144319.

31. Duran C, Gokturk HS, Kulaksizoglu M, Bakdik S, Unler GK, et al. (2012) Frequency of Thyroid Nodules among Patients with Colonic Polyps. Gastroenterol Res Pract 2012: 178570.

32. Mousa U, Anil C, Demir CC, Bozkus Y, Ozturk K, et al. (2019) Thyroid Nodules are More Prevalent in Subjects with Colon Polyps, Independent of Insulin Resistance. Med Princ Pract 28: 418-424.

33. Donatini B, Le Blaye I (2018) Patients with Hashimoto Thyroiditis (HT) Plus Periodontitis (PO) Have a More Frequent Destruction of Hyaluronic Acid (HA) and Medical History of Adenocarcinoma (AC). Proceedings of the $11^{\text {th }}$ Congress of Autoimmunity, Elsevier, Lisbon, Portugal.

34. Donatini B, Brunissen F, Pereira J, Grandchamp M, Flourat A, et al. (2018) Higher Levels of Exhaled Dimethylcyclopropane in Patients with Small Intestinal Bowel Overgrowth, Periodontitis when Associated with a Medical History of Cancer. J Clin Case Stu 3.

35. Donatini B, Le Blaye I (2017) Periodontitis (PO) is Associated with Oral Herpes or Mouth Ulcerations Plus Jejunoduodenal Reflux. AMEC, Monte Carlo, Monaco.

36. Donatini B (2017) Accumulation of Hyaluronic acid (HA): A Risk for Thyroiditis? AMWC 2017, Monaco.

37. Singleton PA (2014) Hyaluronan Regulation of Endothelial Barrier Function in Cancer. Adv Cancer Res 123: 191-209.

38. Petrey AC, de la Motte CA (2014) Hyaluronan, A Crucial Regulator of Inflammation. Front Immunol 5: 101.

39. Zlobec I, Terracciano L, Tornillo L, Gunthert U, Vuong T, et al. (2008) Role of RHAMM within the Hierarchy of Well-Established Prognostic Factors in Colorectal Cancer. Gut 57: 1413-1419.

40. Wu RL, Huang L, Zhao HC, Geng XP (2017) Hyaluronic Acid in Digestive Cancers. J Cancer Res Clin Oncol 143: 1-16.
41. Donatini B (2019) Intérêt de l'échographie abdominale pour l'analyse des vidanges, des reflux et de la tonicité gastro-duodénojéjuno-iléale. HEGEL 9: 1-7.

42. Lachmann R, Loenenbach A, Waterboer T, Brenner N, Pawlita M, et al. (2018) Cytomegalovirus (CMV) Seroprevalence in the Adult Population of Germany. PLoS One 13: e0200267.

43. Shukla SK, Prasad KN, Tripathi A, Singh A, Saxena A, et al. (2011) Epstein-Barr Virus DNA Load and Its Association with Helicobacter pylori Infection in Gastroduodenal Diseases. Braz J Infect Dis 15: 583-590.

44. Sugano N, Ikeda K, Oshikawa M, Idesawa M, Tanaka H, et al. (2004) Relationship between Porphyromonas gingivalis, Epstein-Barr Virus Infection and Reactivation in Periodontitis. J Oral Sci 46: 203-206.

45. Cardenas-Mondragon G, Carreon-Talavera R, Camorlinga-Ponce M, Gomez-Delgado A, Torres J, et al. (2013) Epstein Barr Virus and Helicobacter pylori Co-Infection are Positively Associated with Severe Gastritis in Pediatric Patients. PLoS One 8: e62850.

46. Pawelec G, Derhovanessian E (2011) Role of CMV in Immune Senescence. Virus Res 157: 175-179.

47. Strindhall J, Skog M, Ernerudh J, Bengner M, Lofgren S, et al. (2013) The Inverted CD4/CD8 Ratio and Associated Parameters in 66-YearOld Individuals: The Swedish HEXA Immune Study. Age (Dordr) 35: 985-991.

48. Nevalainen T, Kananen L, Marttila S, Jylhava J, Mononen N, et al. (2017) Obesity Accelerates Epigenetic Aging in Middle-Aged but Not in Elderly Individuals. Clin Epigenetics 9: 20.

49. Mitmaker EJ, Tabah R, How J (2019) Thyroid Nodule DNA Methylation Signatures: An Important Diagnostic Annotation. Clin Cancer Res 25: 457-459.

50. Barros-Filho MC, Dos Reis MB, Beltrami CM, de Mello JBH, Marchi FA, et al. (2019) DNA Methylation-Based Method to Differentiate Malignant From Benign Thyroid Lesions. Thyroid 29: 1244-1254.

51. Yim JH, Choi AH, Li AX, Qin H, Chang S, et al. (2018) Identification of Tissue-Specific DNA Methylation Signatures for Thyroid Nodule Diagnostics. Clin Cancer Res 25: 544-551.

52. White MG, Nagar S, Aschebrook-Kilfoy B, Jasmine F, Kibriya MG, et al. (2016) Epigenetic Alterations and Canonical Pathway Disruption in Papillary Thyroid Cancer: A Genome-wide Methylation Analysis. Ann Surg Oncol 23: 2302-2309.

53. Stephen JK, Chen KM, Merritt J, Chitale D, Divine G, et al. (2018) Methylation Markers Differentiate Thyroid Cancer From Benign Nodules. J Endocrinol Invest 41: 163-170.

54. Maljaarsa PW, Peters HP, Melab DJ, Masclee AA (2008) Ileal brake: A Sensible Food Target for Appetite Control. A Review. Physiol Behav 95: 271-281.

55. Van Citters GW, Lin HC (2006) Ileal Brake: Neuropeptidergic Control of Intestinal Transit. Curr Gastroenterol Rep 8: 367-373.

56. Shin HS, Ingram JR, McGill AT, Poppitt SD (2013) Lipids, CHOs, Proteins: Can all Macronutrients Put a 'Brake' on Eating? Physiol Behav 120: 114-123.

57. Mesa F, Magan-Fernandez A, Castellino G, Chianetta R, Nibali L, et al. (2019) Periodontitis and Mechanisms of Cardiometabolic Risk: Novel Insights and Future Perspectives. Biochim Biophys Acta Mol Basis Dis 1865: 476-484.

58. Solini A, Suvan J, Santini E, Gennai S, Seghieri M, et al. (2019) Periodontitis Affects Glucoregulatory Hormones in Severely Obese Individuals. Int J Obes (Lond) 43: 1125-1129. 
59. Fujita K, Tokuda H, Yamamoto N, Kainuma S, Kawabata T, et al. (2017) Incretins Amplify TNF- $\alpha$-stimulated IL-6 Synthesis in Osteoblasts: Suppression of the IKB/NF-KB pathway. Int J Mol Med 39: 1053 1060.

60. Bouwman JJM, Visseren FLJ, Bouter KP, Diepersloot RJA (2008) Infection-Induced Inflammatory Response of Adipocytes in vitro. Int J Obes (Lond) 32: 892-901.

61. Su Y, Zhang YL, Zhao M, Zhang HQ, Zhang X, et al. (2019) Association between Thyroid Nodules and Volume and Metabolic Syndrome in an lodine-Adequate Area: A Large Community-Based Population Study. Metab Syndr Relat Disord 17: 217-222.

62. Zheng L, Yan W, Kong Y, Liang P, Mu Y (2015) An Epidemiological Study of Risk Factors of Thyroid Nodule and Goiter in Chinese Women. Int J Clin Exp Med 8: 11379-11387.

63. Guo W, Tan L, Chen W, Fan L, Chen Y, et al. (2019) Relationship between Metabolic Syndrome and Thyroid Nodules and Thyroid Volume in an Adult Population. Endocrine 65: 357-364.
64. Chen Y, Zhu C, Chen Y, Wang N, Li Q, et al. (2018) The Association of Thyroid Nodules with Metabolic Status: A Cross-Sectional SPECTChina Study. Int J Endocrinol 2018: 6853617.

65. Blanc E, Ponce C, Brodschi D, Nepote A, Barreto A, et al. (2015) Association between Worse Metabolic Control and Increased Thyroid Volume and Nodular Disease in Elderly Adults with Metabolic Syndrome. Metab Syndr Relat Disord 13: 221-226.

66. Karachaliou M, de Sanjose S, Waterboer T, Roumeliotaki T, Vassilaki M, et al. (2018) Is Early Life Exposure to Polyomaviruses and Herpesviruses Associated with Obesity Indices and Metabolic Traits in Childhood? Int J Obes (Lond) 42: 1590-1601.

67. Fleck-Derderian S, McClellan W, Wojcicki JM (2017) The Association between Cytomegalovirus Infection, Obesity, and Metabolic Syndrome in U.S. Adult Females. Obesity (Silver Spring) 25: 626-633.

68. Hamer M, Batty GD, Kivimaki M (2016) Obesity, Metabolic Health, and History of Cytomegalovirus Infection in the General Population. J Clin Endocrinol Metab 101: 1680-1685. 